\title{
Profil Pengetahuan Dan Proses Kognitif Peserta Didik Pada Sub Materi Vertebrata
}

\author{
Widia Narasanti Agustin ${ }^{1)}$, Purwati Kuswarini Suprapto' ${ }^{2)}$, Vita Meylani ${ }^{3)}$ \\ Pendidikan Biologi, Fakultas Keguruan dan Ilmu Pendidikan, Universitas Siliwangi \\ email: widianarasanti5@gmail.com
}
APA Citation: Agustin., W. N., Suprapto., P. K., \& Meylani., V. (2021). Profil Pengetahuan Kognitif Peserta Didik Mengenai Sub Materi Vertebrata. Quagga: Jurnal Pendidikan dan Biologi, 13(1), 14-25. doi: 10.25134/quagga.v13i1.3368.

Received: 06-08-2020

Accepted: $15-10-2020$

Published: 01-01-2021

\begin{abstract}
Abstrak: Penelitian ini bertujuan untuk mengetahui profil pengetahuan kognitif peserta didik dalam pembelajaran biologi mengenai sub materi vertebrata. Jenis penelitian ini merupakan penelitian kualitatif deskriptif. Pengumpulan data dilakukan dengan memberikan instrument hasil belajar mengenai sub materi vertebrata yang dikerjakan oleh 30 peserta didik kelas X MIPA. Dilakukan pula wawancara bersama guru biologi dan beberapa peserta didik untuk mendapatkan keabsahan data dari soal tes yang sudah dikerjakan. Tes hasil belajar mencakup beberapa indikator dalam dimensi kognitif, yaitu dimensi ranah pengetahuan kognititf yang terdiri dari $\mathrm{K} 1$ dan K2, serta dimensi ranah proses kognitif yang terdiri dari C1-C5. Data dianalisis dengan cara mencari rata-rata nilai dan rata-rata skor dari masing-masing indikator pada ranah kognitif. Berdasarkan hasil analisis, diperoleh data sebagai berikut: 1) Dimensi pengetahuan kognitif peserta didik lebih baik pada pengetahuan faktual;2) Dimensi proses kognitif yang dikuasai oleh peserta didik adalah pada C1 (proses mengingat), sedangkan yang kurang dikuasai oleh peserta didik adalah pada C4 (proses menganalisis); 3) Penguasaan konsep peserta didik pada sub materi vertebrata yaitu materi yang dianggap mudah oleh peserta didik merupakan materi yang bersifat umum karena berkaitan dengan kehidupan sehari-hari, diantaranya yaitu mengenai pengertian vertebrata, pembahasan mengenai hewan pisces, dan materi mengenai seputar reptile; 4) Kesulitan peserta didik dalam mempelajari sub materi vertebrata adalah dalam segi mendalami materi, karena banyaknya jenis hewan vertebrata yang harus dikuasai oleh peserta didik. Dan dalam segi menganalisis berbagai macam hewan vertebrata membuat peserta didik kesulitan untuk dapat memahami bentuk soal cerita mengenai hewan vertebrata yang ada dalam kehidupan sehari-hari.
\end{abstract}

Kata kunci: Pengetahuan Kognitif; Proses Kognitif; Sub Materi Vertebrata

Abstract: This study aims to determine the cognitive knowledge profile of students in learning biology about vertebrate sub material. This type of research is a descriptive qualitative research. Data collection was carried out by giving learning outcomes instruments about vertebrate sub material which was done by 30 students of Class X math and science. Interview tests were also carried out with biology teachers and some students to get the validity of the data from the test questions that had been done. The learning outcomes test includes several indicators in the cognitive dimension, namely the cognitive knowledge domain consisting of K1 and K2, as well as the cognitive process domain consisting of C1-C5. Data were analyzed by finding the average value and the average score of each indicator in the cognitive domain. Based on the analysis results, the following data are obtained: 1) Dimensions of cognitive knowledge of students are better on factual knowledge; 2) Dimensions of cognitive processes that are mastered by students are at C1, while those less mastered by students are at C4; 3) Mastery of the concept of students in vertebrate sub material, namely material that is considered easy by students is general material because it relates to everyday life, including the understanding of vertebrates, discussion of animal pisces, and material about reptiles; 4) The difficulty of students in learning vertebrate sub material is in terms of deepening the material, because of the many types of vertebrate animals that must be mastered by students. And in terms of analyzing various kinds of vertebrate animals, it makes it hard for students to understand the form of story problems about vertebrate animals that exist in everyday life.

Keywords: Cognitive Knowledge; Cognitive Process; Vertebrate Sub Material 


\section{PENDAHULUAN}

Pendidikan merupakan suatu hal yang sangat penting bagi perkembangan kehidupan manusia, baik perkembangan pengetahuan, tingkah laku maupun keterampilan. Pendidikan pada dasarnya adalah suatu proses untuk membantu manusia dalam mengembangkan dirinya sehingga mempunyai kemampuan dalam menghadapi setiap perubahan yang terjadi dimasa mendatang. Menurut Trianto (2012), pendidikan yang mampu mendukung pembangunan dimasa mendatang adalah pendidikan yang mampu mengembangkan potensi peserta didik sehingga peserta didik mampu menghadapi dan memecahkan permasalahan dalam kehidupan yang dialami. Dari aktifitas belajar, peserta didik dapat mengasah dan melatih kemampuannya dalam mengembangkan potensi dirinya masingmasing dibidang pendidikan.

Belajar menurut Rifa'i dan Anni (2016) merupakan proses penting bagi perubahan perilaku manusia yang mencakup segala sesuatu hal yang dipikirkan dan dikerjakan oleh seseorang. Perubahan yang terjadi pada diri peserta didik dapat berupa perubahan kognitif, afektif, dan juga psikomotor. Pengetahuan kognitif adalah salah satu ranah yang menjadi penilaian terpenting dalam proses pembelajaran. Secara umum menurut Anderson \& Krathwol (2001) menyebutkan bahwa, kognitif diartikan sebagai potensi intelektual yang terdiri dari dua dimensi, yaitu dimensi pengetahuan kognitif yang terdiri dari empat jenis pengetahuan yaitu pengetahuan faktual (K1), pengetahuan konseptual (K2), pengetahuan prosedural (K3), dan pengetahuan metakognitif (K4). Dan dimensi proses kognitif yang terbagi menjadi beberapa indikator proses kognitif yaitu: proses kognitif mengingat (C1), proses kognitif memahami (C2), proses kognitif mengaplikasikan (C3), proses kognitif menganalisis (C4), proses kognitif mengevaluasi (C5), dan proses kognitif mencipta (C6).

\footnotetext{
Kognitif berarti persoalan yang menyangkut kemampuan untuk mengembangkan kemampuan berpikir (akal). Pengetahuan kognitif merupakan kemampuan peserta didik dalam melaksanakan aktivitas otak (berpikir) untuk memperoleh suatu pengetahuan dan pemahaman yang telah diterimanya selama kegiatan pembelajaran.
}

Dalam belajar biologi di sekolah banyak menekankan pengetahuan kognitif peserta didik, untuk melatih kemampuan berpikirnya. Sub materi vertebrata merupakan salah satu bagian dalam biologi yang mencakup berbagai penjelasan mengenai macam jenis hewan bertulang belakang yang ada di dunia. Pembelajaran mengenai vertebrata dalam biologi ini sangat bermanfaat bagi peserta didik dalam mempelajari dan memahami materi. Sub materi vertebrata ini merupakan materi biologi yang bersifat kongkrit, artinya dapat diliat dan dianalisis secara langsung. Selain itu juga vertebrata ini berhubungan dengan kehidupan sehari-hari, sebagai dasar dalam mempelajari ilmu-ilmu lain seperti ilmu mengenai keanekaragaman dalam ekologi, ilmu peternakan, dan ilmu kedokteran hewan yang dapat bermanfaat bagi kehidupan.

Proses pembelajaran Biologi memerlukan pemahaman dan ketelitian terhadap materi yang diajarkan. Hal itu karena biologi mengkaji peristiwa, fakta, konsep, dan generalisasi yang berkaitan dengan alam sekitar. Berdasarkan hasil observasi dan diskusi yang dilakukan dengan guru biologi kelas X MIPA di salah satu SMA di Kota Tasikmalaya, terdapat sekiranya $70 \%$ peserta didik yang sudah memenuhi nilai KKM dalam mata pelajaran biologi pada sub materi vertebrata. Dalam hasil observasi, peserta didik lebih paham membahas mengenai hewanhewan yang biasa mereka lihat pada kehidupan sehari-hari mereka. Tetapi, diketahui bahwa selama proses pembelajarannya guru masih dominan menggunakan metode ceramah, sehingga proses pembelajaran masih terbilang melakukan proses transfer pengetahuan dari guru ke peserta didik saja tanpa melibatkan peserta didik secara aktif. Hal tersebut terlihat saat peserta didik hanya mencatat dan mendengarkan materi yang disampaikan oleh pendidik tanpa melakukan kegiatan yang seharusnya dapat melatih pengetahuan kognitif peserta didik dalam kegiatan belajar. Berdasarkan hal tersebut, agar dalam pembelajaran biologi khususnya mengenai sub materi vertebrata dapat berjalan dengan baik maka seorang pendidik harus mengetahui kemampuan pengetahuan kognitif peserta didiknya terlebih dahulu. 


\section{METODOLOGI PENELITIAN}

Penelitian dilaksan akan di kelas X MIPA 4 di salah satu SMAN di Tasikmalaya. Dalam penelitian ini, jenis penelitian yang digunakan adalah penelitian kualitatif deskriptif.

Penelitian ini bertujuan untuk mengetahui profil pengetahuan kognitif peserta didik pada sub materi vertebrata di kelas X MIPA SMAN di Tasikmalaya. Data yang diperoleh kemudian akan dideskripsikan dan dianalisa untuk mengetahui pengetahuan kognitif peserta didik.

Pada penelitian ini digunakan diikuti oleh 30 partisipan yang merupakan peserta didik kelas X MIPA SMAN di Tasikmalaya. Dengan teknik pengambilan sampelnya yaitu menggunakan purposive sampling. Instrumen penelitian yang digunakan dalam penelitian ini adalah soal tes hasil belajar berbentuk multiple choice. Tes dilakukan satu tahap yaitu posttest untuk mengukur hasil belajar. Selain itu, dalam penelitian ini juga dilakukannya triangulasi data yang bertujuan untuk melihat keabsahan data dengan cara mencocokan atau membandingkan data yang didapatkan dengan sesuatu yang lain, salah satunya dengan mengumpulkan data melalui hasil wawancara bersama guru biologi SMAN di Tasikmalaya dan peserta didik kelas $X$ MIPA SMAN di Tasikmalaya. Wawancara pada penelitian ini merupakan wawancara tidak terstruktur dan dilakukan secara tidak langsung yaitu melalui media elektronik karena terkendala satu dan lain hal. Tujuan dari wawancara ini adalah untuk mendapatkan informasi yang mendalam dan mendukung mengenai apa yang telah didapatkan dari hasil mengerjakan soal mengenai sub materi vertebrata, serta memastikan kemampuan pengetahuan kognitif yang dimiliki oleh peserta didik.

\section{HASIL DAN PEMBAHASAN}

\section{a. Hasil Penelitian}

Setelah pelaksanaan tes, peneliti memeriksa dan mengkoreksi jawaban peserta didik. Pemeriksaan hasil tes tersebut kemudian diklasifikasikan sesuai dengan kategori-kategori dimensi kognitif yang terdiri dari ranah dimensi pengetahuan kognitif dan dimensi proses kognitif. Dalam penelitian ini, dimensi pengetahuan kognitif yang diteliti menggunakan acuan dari Taksonomi Bloom yang sudah direvisi, yang terdiri dari pengetahuan faktual (K1) dan pengetahuan konseptual (K2). Dan untuk dimensi proses kognitif yang digunakan terdiri dari proses mengingat $(\mathrm{C} 1)$, proses memahami (C2), proses mengaplikasikan (C3), proses mengalisis (C4), dan proses mengevaluasi (C5). Selanjutnya, pemberian wawancara mengenai pembelajaran biologi tentang sub materi vertebrata.

Kemudian peneliti membuat laporan akhir dengan menganalisis data-data yang telah diperoleh selama penelitian. Berdasarkan 37 soal tes hasil belajar mengenai sub materi vertebrata, terdapat 17 soal pertanyaan yang termasuk dalam dimensi pengetahuan kognitif $\mathrm{K} 1$, dan 20 soal pertanyaan yang termasuk dalam dimensi pengetahuan kognitif K2. Dan 4 soal diantaranya adalah jenis soal dimensi kognitif proses mengingat (C1), 11 soal diantaranya adalah jenis soal dimensi kognitif proses memahami (C2), 5 soal lainnya termasuk jenis soal dimensi kognitif proses mengaplikasikan (C3), 9 soal lainnya termasuk jenis soal dimensi kognitif proses menganalisis (C4), dan 8 soal lagi merupakan jenis soal dimensi kognitif proses mengevaluasi (C5).

Tes hasil belajar ini bertujuan untuk mengetahui bagaimana hasil pengetahuan kognitif peserta didik pada ranah dimensi pengetahuan kognitif yang terdiri dari $\mathrm{K} 1$ dan $\mathrm{K} 2$, dan proses kognitif yang terdiridari $\mathrm{C} 1-\mathrm{C} 5$. Adapun data hasil pengisian soal hasil belajar yang telah dilakukan peserta didik disajikan pada tabel 1 . 
Tabel 1. Skor Hasil Tes Online Tingkat Dimensi

PengetahuanKognitif dan Proses Kognitif Pada Sub Materi Vertebrata

\begin{tabular}{|c|c|c|c|c|c|c|c|c|c|c|}
\hline \multirow[t]{2}{*}{$\begin{array}{l}\mathbf{N} \\
\mathbf{0}\end{array}$} & \multirow[t]{2}{*}{ Nama } & \multicolumn{5}{|c|}{$\begin{array}{c}\text { Perolehan Skor Proses } \\
\text { kognitif }\end{array}$} & \multirow[t]{2}{*}{$\begin{array}{c}\text { Jumlah } \\
\text { Skor }\end{array}$} & \multicolumn{2}{|c|}{$\begin{array}{c}\text { Perolehan Skor } \\
\text { Pengetahuan } \\
\text { Kognitif }\end{array}$} & \multirow[t]{2}{*}{ NILAI } \\
\hline & & C1 & $\mathrm{C2}$ & $\mathrm{C3}$ & $\mathrm{C4}$ & C5 & & K1 & K2 & \\
\hline 1 & A P & 3 & 7 & 3 & 5 & 5 & 23 & 12 & 11 & 62,16 \\
\hline 2 & A Z & 4 & 5 & 4 & 7 & 4 & 24 & 12 & 12 & 64,86 \\
\hline 3 & A N & 3 & 7 & 2 & 3 & 4 & 19 & 11 & 8 & 51,35 \\
\hline 4 & D N & 3 & 6 & 4 & 1 & 5 & 19 & 11 & 8 & 51,35 \\
\hline 5 & $\mathrm{D} \mathrm{M}$ & 4 & 8 & 2 & 3 & 4 & 23 & 13 & 10 & 62,16 \\
\hline 6 & E N & 4 & 3 & 4 & 5 & 3 & 20 & 9 & 11 & 54,05 \\
\hline 7 & F A & 1 & 3 & 1 & 0 & 3 & 8 & 4 & 4 & 21,62 \\
\hline 8 & F S & 2 & 6 & 4 & 4 & 5 & 23 & 12 & 11 & 62,16 \\
\hline 9 & F F & 1 & 2 & 1 & 2 & 1 & 7 & 4 & 3 & 18,92 \\
\hline 10 & F R & 2 & 6 & 2 & 2 & 5 & 17 & 8 & 9 & 45,95 \\
\hline 11 & G A & 3 & 5 & 4 & 5 & 5 & 22 & 11 & 11 & 59,46 \\
\hline 12 & I M & 4 & 8 & 5 & 7 & 4 & 28 & 14 & 14 & 75,67 \\
\hline 13 & I D & 2 & 6 & 3 & 2 & 3 & 16 & 9 & 7 & 43,24 \\
\hline 14 & M S & 4 & 9 & 4 & 6 & 5 & 27 & 15 & 12 & 72,97 \\
\hline 15 & M F & 3 & 6 & 4 & 5 & 4 & 25 & 13 & 12 & 67,57 \\
\hline 16 & $\mathrm{M} \mathrm{A}$ & 3 & 6 & 3 & 5 & 6 & 21 & 10 & 11 & 56,76 \\
\hline 17 & M R & 4 & 9 & 4 & 5 & 6 & 29 & 13 & 16 & 78,38 \\
\hline 18 & MT A & 3 & 4 & 2 & 4 & 7 & 18 & 8 & 10 & 48,65 \\
\hline 19 & RJ & 2 & 4 & 1 & 4 & 2 & 13 & 6 & 7 & 35,13 \\
\hline 20 & R W & 3 & 6 & 1 & 3 & 7 & 22 & 11 & 11 & 59,46 \\
\hline 21 & R N & 3 & 5 & 2 & 5 & 5 & 22 & 9 & 13 & 59,46 \\
\hline 22 & S A & 3 & 7 & 2 & 4 & 5 & 21 & 11 & 10 & 56,76 \\
\hline 23 & $\mathrm{~S}$ & 1 & 4 & 2 & 1 & 4 & 13 & 4 & 9 & 35,13 \\
\hline 24 & S N & 3 & 6 & 5 & 8 & 8 & 32 & 15 & 17 & 86,48 \\
\hline 25 & S L & 3 & 8 & 3 & 6 & 6 & 26 & 13 & 13 & 70,27 \\
\hline 26 & $\mathrm{~S} \mathrm{H}$ & 1 & 1 & 0 & 3 & 1 & 6 & 3 & 3 & 13,51 \\
\hline 27 & T Y & 4 & 7 & 3 & 4 & 4 & 22 & 11 & 11 & 59,46 \\
\hline 28 & $\mathrm{VO}$ & 4 & 11 & 5 & 7 & 6 & 33 & 16 & 17 & 89,19 \\
\hline 29 & Y L & 3 & 8 & 4 & 7 & 5 & 28 & 13 & 15 & 75,67 \\
\hline 30 & $\mathrm{ZG}$ & 3 & 7 & 5 & 7 & 6 & 28 & 13 & 15 & 75,67 \\
\hline \multicolumn{2}{|c|}{ Rata-rata } & 2,87 & 6 & 2,97 & $\mathbf{4 , 3 3}$ & 4,6 & 21,17 & 10,47 & 10,7 & 57,12 \\
\hline \multicolumn{2}{|c|}{$\begin{array}{c}\text { Rata-rata } \\
\text { Persoal }\end{array}$} & 0,72 & $\mathbf{0 , 5 5}$ & 0,59 & $\overline{0,48}$ & $\mathbf{0 , 5 8}$ & & 0,61 & 0,54 & \\
\hline
\end{tabular}

Keterangan:

$\mathrm{C} 1$ :Tahap Proses Mengingat

C2 :Tahap Proses Memahami

C3 :Tahap Proses Mengaplikasikan

C4 :Tahap Proses Menganalisis

C5 :Tahap Proses Mengevaluasi

K1 : Pengetahuan Faktual

K2 : Pengetahuan Konseptual 
b. Pembahasan

a) Ranah Pengetahuan Kognitif Peserta Didik Pada Dimensi Pengetahuan Mengenai Sub Materi Vertebrata

Berdasarkan tabel 1 terlihat bahwa ada beberapa peserta didik yang mendapatkan perolehan skor terendah pada dimensi pengetahuan kognitif, yaitu $\mathrm{FF}$ dan $\mathrm{SH}$ yang memperoleh skor terkecil pada dimensi pengetahuan kognitif. FF mendapatkan jumlah 7 skor dari kedua dimensi pengetahuan kognitif, untuk K1 ia hanya berhasil memperoleh 3 skor dari 17 skor maksimum yang ada pada $\mathrm{K} 1$, dan pada K2 ia hanya berhasil memperoleh 4 skordari 20 skor maksimum yang ada pada K2. Sedangkan untuk SH mendapatkan jumlah 6 skor dari kedua dimensi pengetahuan kognitif, untuk dimensi pengetahuan K1 dan K2 masingmasing hanya dapat memperoleh 3 skor saja. Sedangkan skor tertinggi pada ranah dimensi pengetahuan kognitif, didapatkan oleh VO. Ia mendapatkan jumlah perolehan skor tertinggi dengan jumlah keseluruhan adalah 33 skor. Pada dimensi K1 ia mendapatkan perolehan skor sebanyak 16 dari 17 skor maksimum pada soal pengetahuan faktual. Dan pada dimensi K2 ia memperoleh skor sebanyak 17 dari 20 skor maksimum pada soal pengetahuan konseptual mengenai sub materi vertebrata.

Rata-rata skor yang didapatkan oleh 30 peserta didik pada ranah dimensi $\mathrm{K} 1$ adalah 0,61 , dan rata-rata skor untuk dimensi $\mathrm{K} 2$ adalah 0,54 . Untuk hasil perbandingan antara rata-rata persoal seluruh skor pada ranah dimensi pengetahuan kognitif, dapat dilihat pada gambar berikut ini.

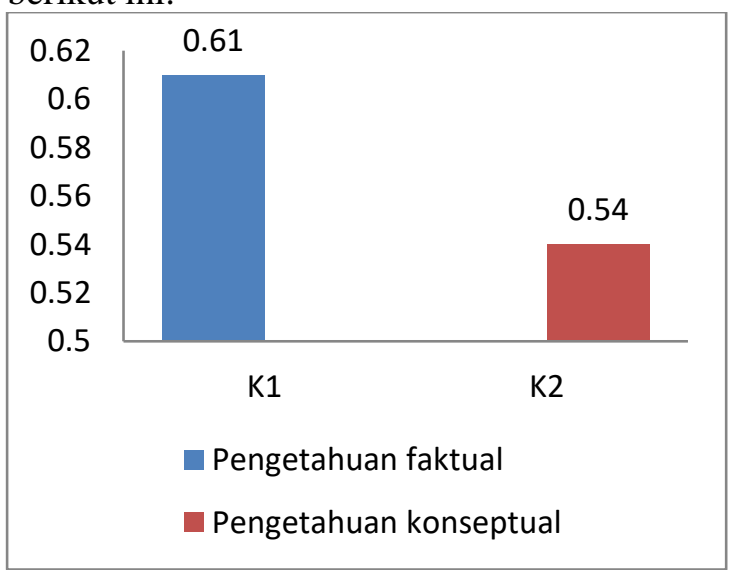

Gambar 1. Diagram Batang Rata-rata Skor Tiap Indikator Pada Dimensi Pengetahuan Kognitif
Berdasarkan gambar 1 tersebut terlihat bahwa rata-rata skor untuk K1 lebih besar daripada rata-rata skor untuk $\mathrm{K} 2$, itu artinya bentuk soal pertanyaan yang disajikan pada dimensi $\mathrm{K} 1$ cenderung lebih bisa dimengerti oleh peserta didik dibandingkan dengan dimensi K2. Hal tersebut diakibatkan karena pada pengetahuan faktual jenis soalnya bersifat terminologi, sesuai dengan KBBI terminology artinya adalah tentang peristilahan (kata-kata) dan mengenai ilmu tentang definisi suatu istilah tertentu yang diketahui dan mudah dimengerti oleh peserta didik. Selain itu, Bloom berpendapat bahwa pengetahuan konseptual merupakan pengetahuan tentang bentuk-bentuk pengetahuan yang lebih kompleks dan terorganisasi, serta jenis pengetahuan ini mencakup pengetahuan tentang klasifikasi dan kategori, prinsip dan generalisasi, dan tentangteori, model serta struktur yang ada dalam suatu pembahasan, hal tersebut menyababkan peserta didik lebih mengerti mengenai pengetahuan yang bersifat faktual dibanding pengetahuan konseptual.

\section{b) Ranah Pengetahuan Kognitif Peserta Didik Pada Dimensi Proses Kognitif Mengenai Sub Materi Vertebrata}

Berdasarkan tabel 1 tersebut, terlihat ada beberapa peserta didik yang tidak mendapatkan skor atau mempunyai skor 0 pada beberapa ranah dimensi proses kognitif. Peserta didik tersebut diantaranya adalah FA, dan $\mathrm{SH}$, selain itu keduanya juga merupakan peserta didik yang termasuk dalam kategori gagal karena mempunyai skor dan nilai yang terkecil. Terkait hal tersebut, peneliti melakukan wawancara dengan salah satu dari mereka yaitu $\mathrm{SH}$, karena termasuk peserta didik yang mempunyai skor paling kecil diantara 30 peserta didik lainnya. Untuk mengetahui kenapa hal tersebut bisa terjadi, wawancaranya dipaparkan sebagai berikut:

Peneliti : Apakah kamu mengalami gangguan saat mengerjakan soal?

$\mathrm{SH} \quad$ : Gangguan internet sih tidak ada, tetapi soal yang diberikan terlalu susah

Peneliti : Saat mengerjakannya, apakah ada yang membantu kamu atau kamu mengerjakan sendiri?

SH :Ada yang dibantuin sedikit, karena banyak soal yang gangerti

Peneliti :Apakah saat mengerjakannya kamu melihat buku atau internet? 
SH

:Liat, tapi gasemuanya liat internet, Cuma yang bisa di searching doang, sisanya hasil ngerjain sendiri

Peneliti :Apakah kamu mengerti tentang materi vertebrata?

SH :Sedikit bu

Peneliti: Menurut kamu apakah materi vertebrata sudah diajarkan dengan baik disekolah?

SH : Sebenernya bu, materi awal doang yang masih saya perhatiin, pas udah 30 menit dijelasin lagi saya ngantuk. Tapi dikitdikit mah ngerti

Peneliti: Tapi, apa kamu merasa malas atau tertekan saat mengerjakan soal vertebrata yang ibu berikan?

SH : Yang penting ngerjainsihbu, soalnya kan harus

Peneliti : Apakah kamu senang belajar biologi?

SH : Lumayan bu, soalnya ga sepusing fisika.

Kutipan wawancara tersebut menunjukkan bahwa SH termasuk peserta didik yang biasasaja, artinya ia selalu mengerjakan tugas yang diberikan oleh guru tetapi tidak peduli akan mendapatkan skor baik atau buruk. Berdasarkan tes hasil belajar yang telah dilakukan, $\mathrm{SH}$ mendapatkan skor terkecil yaitu jumlah skor keseluruhan sebesar 6 skor dengan perolehan nilai keseluruhan 13,51 yang termasuk dalam kategori gagal. Ia cenderung termasuk murid yang memperhatikan materi diawal saja, tanpa mempedulikan materi yang lainnya. Dan ia termasuk kedalam murid yang hanya mengikuti alur pembelajaran tanpa ikut berperan aktif didalam pembelajaran tersebut.

Berdasarkan hasil wawancara dengan peserta didik yang mendapatkan nilai dan skor yang terkecil, dapat disimpulan bahwa peserta didik cenderung mengarang dalam menjawab soal yang diberikan, karena menurutnya banyak soal pertanyaan yang dianggap sulit, sehingga menyebabkan rendahnya skor dan nilai yang didapatkan oleh peserta didik. Hal tersebut sesuai dengan pendapat menurut Hidayati $\underline{(2010: 75)}$ yakni jika seseorang mengalami kesulitan dalam mengerjakan sesuatu maka nantinya seseorang tersebut akan cenderung membuat kesalahan pada apa yang telah dikerjakannya.

Selain terdapat peserta didik yang mendapatkan skor dan nilaiterkecil, ada pula peserta didik yang mendapat skor dan nilai yang besar dan termasuk dalam kategori baik sekali. Ada 2 peserta didik yang termasuk dalam kategori tersebut, yaitu SN yang mendapatkan jumlah skor 32 dengan perolehan nilai 86,48 dan VO yang mendapatkan jumlah skor 33 dengan perolehan nilai 89,19. Berarti bisa dikatakan bahwa keduanya mempunyai pengetahuan kognitif yang baik. Untuk membuktikannya, peneliti melakukan wawancara bersama salah satu dari mereka terkait tes hasil belajar yang sudah mereka lakukan. Wawancara ini dilakukan bersama VO yang mendapatkan nilai tertinggi dari 30 peserta didik yang mengerjakan soal hasil belajar mengenai sub materi vertebrata. Wawancaranya dipaparkan sebagai berikut:

Peneliti : apakah kamu mengerjakan soal sambil melihat buku atau internet?

Vo :Soalnya lumayan susah bu. Saya menggunakan internet sebagian karena tidak seтиа jawabannya ada di internet, sisanya saya menjawab dengan kemampuan sendiri bu

Peneliti :Apakah kamu tau materi yang kamu kerjakan itu termasuk materi pembahasan apa?

Vo $\quad:$ Tau bu, mengenai hewan yang memiliki tulang belakang atau vertebrata

Peneliti: Nah bagus, menurut kamu bagaimana pembahasan tentang vertebrata di sekolah? Apakah sudah dijelaskan dengan rinci? Dan apakah kamu mengerti dengan penjelasan materi dari guru disekolah?

Vo : Karena waktu belajar disekolah sebentar tidak terlalu rinci bu gurunya menjelaskan, jadi kaya yang uтum-umum aja menjelaskannya bu. Penjelasannya ada yang ngerti ada yang engga, tapi banyaknya ngerti soalnyakan hewan vertebrata uтum di kehidupan sehari-hari

Peneliti : Oke. Apakah kamu suka baca referensi lain mengenai hewan-hewan verteb? Misalnya kamu suka membaca buku atau semacamnya?

Vo : Paling baca-baca fakta di instagram atau artikel-artikel di internet bu, kalau buku jarang, paling buku pelajaranaja

Peneliti : baik. Apakah biologi termasuk mata pelajaran yang kamu sukai?

Vo $\quad$ : Iya bu saya suka pelajaran biologi..

Dalam kutipan wawancara tersebut menunjukkan bahwa VO mengerjakan sendiri tes hasil belajar yang dikerjakan lewat googleform, walaupun ia menyebutkan ada beberapa soal pertanyaan yang ia searching jawabannya lewat internet. Tetapi dalam percakapan wawancara tersebut terlihat bahwa VO merupakan peserta didik yang selalu 
memperhatikan pelajaran yang disampaikan oleh gurunya disekolah. Dan dalam wawancara tersebut juga ia mengatakan bahwa vertebrata merupakan salah satu materi biologi yang ia sukai karena hewan-hewan vertebrata umumnya adalah hewan-hewan yang sering dijumpai dalam kehidupan sehari-hari, jadi saat memperlajarinya pun ia merasa senang, ditambah lagi ia termasuk seseorang yang menyukai hewan-hewan dan tertarik mempelajarinya lebih mendalam lewat referensi lain di internet.

Berdasarkan hasil wawancara bersama peserta didik yang mendapatkan skor dan nilai tertinggi, dapat disimpulkan bahwa peserta didik tersebut merupakan peserta didik yang mengikuti pembelajaran didalam kelas dengan baik, sehingga bisa menangkap dan memahami materi dengan baik sesuai yang disampaikan oleh guru didalam kelas. Hal tersebut sejalan dengan pendapat Sudjana (2006:28) bahwa perolehan hasil belajar yang diharapkan dapat tercapai apabila peserta didik mampu melibatkan diri untuk aktif dalam belajar sebagai respon terhadap stimulus yang telah diberikan oleh guru.

Untuk keseluruhan perolehan rata-rata skor tiap indikator pada ranah proses kognitif yaitu memperoleh rata-rata skor untuk $\mathrm{C} 1$ sebesar 0,72 , rata-rata skor untuk $\mathrm{C} 2$ sebesar 0,55 , ratarata skor untuk $\mathrm{C} 3$ sebesar 0,59 , rata-rata skor untuk $\mathrm{C} 4$ sebesar 0,48 , dan rata-rata skor untuk C5 yaitu sebesar 0,58. Sehingga dapat disimpulkan bahwa rata-rata skor yang paling kecil adalah pada soal jenis $\mathrm{C} 4$, artinya peserta didik masih kesulitan dalam tahap menganalisis soal vertebrata, karena dalam proses menganalisis dibutuhkan ketelitian dan pemikiran tingkat tinggi. Untuk hasil perbandingan antara rata-rata skor pada ranah dimensi proses kognitif, dapat dilihat pada gambar 2.

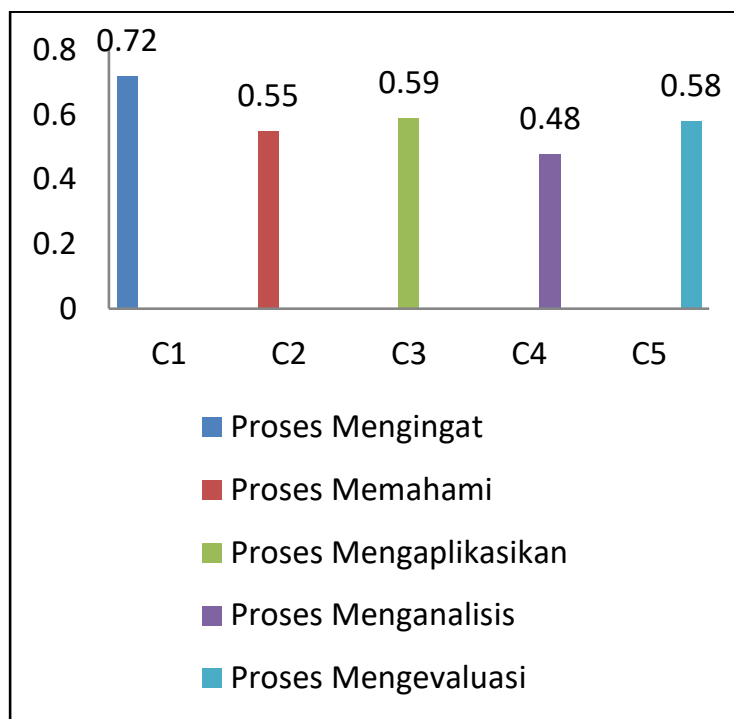

Gambar 2. Diagram Batang Rata-rata

Skor Tiap Indikator Pada Dimensi Proses Kognitif

Berdasarkan gambar 2 tersebut terlihat bahwa rata-rata persoal $\mathrm{C} 1$ merupakan ranah proses kognitif yang mendapatkan rata-rata terbesar, karena banyak peserta didik yang menjawab benar dalam jenis soal $\mathrm{C} 1$, sesuai dengan karakteristik jenis soal $\mathrm{C} 1$ menurut Bloom merupakan kemampuan kognitif yang paling rendah dan paling dasar dalam kawasan kognitif, sehingga jenis soal C1 merupakan jenis soal yang termasuk dalam jenis soal menghapal. Sedangkan rata-rata persoal yang paling rendah terdapat pada soaljenis $\mathrm{C} 4$ yaitu proses menganalisis. Sejalan dengan itu, Bloom mengatakan bahwa proses menganalisis termasuk dalam tingkatan kognitif tingkat tinggi, dengan bentuk soal yang harus dianalisis oleh peserta didik. Hal ini dikarenakan peserta didik belum dibiasakan dalam melakukan analisis soal saat mengerjakan tugas-tugas yang diberikan oleh guru disekolah. Widodo (2006) berpendapat bahwa, sedikitnya pertanyaan guru yang menuntut pemikiran tingkat tinggi kepada peserta didik menunjukkan bahwa pembelajaran disekolah belum melatih peserta didik untuk mengembangkan pemikiran dan penalaran tingkat tinggi. Hal tersebut yang menjadi salah satu faktor rendahnya skor proses analisis yang didapatkan oleh peserta didik.

c) Penguasaan Konsep Peserta didik Pada Sub Materi Vertebrata

Berdasarkan 37 soal tes hasil belajar mengenai sub materi vertebrata yang telah dilakukan, terdapat diantaranya ada 4 bentuk 
soal pertanyaan yang dianggap mudah oleh peserta didik karena pertanyaan tersebut termasuk mendapatkan jumlah yang paling banyak dijawab benar oleh peserta didik. Yang pertama yaitu soal yang membahas mengenai konsep umum dari vertebrata. Soal tersebut termasuk jenis soal $\mathrm{C} 1 \mathrm{~K} 2$, yaitu termasuk dimensi proses kognitif $\mathrm{C} 2$, dan termasuk dimensi pengetahuan $\mathrm{K} 2$, dimana soal tersebut termasuk dalam soal yang umum karena ratarata peserta didik pasti mengetahui arti dari hewan vertebrata tersebut, jadi soal tersebut termasuk dalam soal yang mudah dan banyak dijawab benar oleh peserta didik.

Yang kedua soal yang dianggap mudah yaitu soal yang membahas mengenai alat pernapasan pada anggota hewan pisces, soal tersebut termasuk dalam jenis soal $\mathrm{C} 2 \mathrm{~K} 1$ yaitu termasuk dalam dimensi proses kognitif $\mathrm{C} 2$ dan termasuk dalam dimensi pengetahuan $\mathrm{K} 1$, dalam soal tersebut termasuk jenis soal yang umum dan dapat diketahui oleh siapa pun, oleh sebab itu banyak peserta didik yang menjawab dengan benar. Yang ketiga yaitu ada soal yang temasuk jenis soal C5K2, soal tersebut dianggap mudah oleh peserta didik karena banyak juga peserta didik yang menjawab benar. Soal tersebut membahas mengenai kelompok hewan reptile yang melakukan pergantian sisik, umumnya reptile pasti melakukan pergantian sisik atau pergantian kulit, oleh sebab itu rata-rata peserta didik pasti mengetahui jawabannya. Walaupun soal tersebut termasuk jenis soal dimensi proses C5 dan K2, yang biasanya jenis pertanyaan tersebut harus menggunakan pemikiran tingkat tinggi karena peserta didik harus menganalisis bentuk cerita dari pertanyaan tersebut, tetapi artinya pertanyaan tersebut mudah dipahami dan dimengerti oleh peserta didik.

Yang terakhir, soal yang termasuk jenis soal yang dianggap mudah adalah soal yang membahas mengenai kelompok hewan reptile salah satunya penyu, hewan tersebut selalu menggali pasir, biasanya kelompok hewan tersebut menggali pasir untuk menyimpan anaknya yang berupa telur. Soal tersebut termasuk dalam jenis soal C3K1 yaitu termasuk dimensi proses mengaplikasikan dan termasuk dimensi pengetahuan faktual. Berarti bisa dikatakan soal tersebut termasuk jenis soal pertanyaan yang umum diketahui oleh peserta didik karena banyaknya peserta didik yang menjawab benar pada soal tersebut.
Selain itu, ada juga jenis soal yang dianggap sulit oleh peserta didik karena sedikitnya peserta didik yang menjawab benar pada soal pertanyaan tersebut. Yaitu ada 4 jenis soal pertanyaan yang kebanyakan peserta didik menjawab salah pada pertanyaan tersebut. Yang pertama yaitu jenis soal yang membahas mengenai kelompok hewan aves, soal tersebut merupakan jenis soal yang menganalisis mengenai ordo aves yang mempunyai ciri-ciri mempunyai paruh kuat yang digunakan untuk merobek mangsanya dan memiliki kaki tajam untuk mencengkram. Soal tersebut termasuk dalam jenis soal $\mathrm{C} 4$ dan $\mathrm{K} 2$ yang memerlukan tingkat berpikir yang tinggi untuk menganalisis soal dan jawabannya. Terkait hal tersebut, adapun kutipan wawancara bersama guru biologi SMAN di Tasikmalaya mengenai permasalahan pada soal aves tersebut, dipaparkan sebagai berikut:

Peneliti : Berdasarkan hasil penelitian yang telah saya lakukan, ternyata masih soal yang memabahas mengenai keberagaman jenis aves dianggap sulit oleh siswa, selain itu mereka sulit untuk mengetahui nama ilmiah dari kelompok aves tersebut. Apakah bapa tau penyebab dari sulitnya peserta didik menjawab pertanyaan tersebut?

Guru Bio: Ya mungkin karena mereka belum bisa menangkap atau memahami berbagai macam jenis aves, karena mungkin kan banyak ya, jadi siswa masih merasa kesulitan untuk menghafalnya

Peneliti : Baik, berarti peserta didik mempunyai kesulitan untuk menghafal jenis-jenis hewan aves berdasarkan ciri-cirinya ya pak?

Guru Bio : Iya, karna kan jenis aves itu ada banyak.

Kutipan wawancara tersebut menunjukkan bahwa sedikitnya peserta didik yang menjawab benar mengenai hewan aves tersebut disebabkan karena banyaknya jenis aves yang ada membuat sulitnya peserta didik menghafal nama-nama ilmiah dari kelompok hewan aves. Jika peserta didik tidak mengetahui mengenai nama-nama ilmiah, maka akan membuat peserta didik mengalami kesulitan dalam mengerjakan soal yang menyangkut dengan materi tersebut. Sejalan dengan itu, Yusriya (2014:27) juga mengungkap dalam penelitiannya bahwa materi klasifikasi hewan dengan ciri-ciri yang kompleks dari setiap filum dan kelas serta 
banyaknya nama ilmiah, membuat peserta didik kesulitan dalam memahami materi tersebut.

Soal yang termasuk sulit selanjutnya yaitu termasuk jenis soal C2 dan K2, soal tersebut menyebutkan hewan vertebrata mengenai hewan mamalia laut, yang jarang diketahui oleh sebagian peserta didik. Beberapa pilihan jawaban pada soal tersebut cukup mengecoh peserta didik karena keseluruhan jawaban menunjukan hewan-hewan laut, diantaranya yaitu lumba-lumba, singa laut, kuda laut, kuda nil, dan paus. Akibatnya, banyak peserta didik yang terkecoh oleh pilihan jawaban yang ada, padahal jenis soal tersebut temasuk pada jenissoal yang tingkat berpikirnya rendah, yaitu termasuk dalam kemampuan kognitif proses memahami. Terakhir, soal yang dianggapsulit oleh peserta didik adalah termasuk jenis soal $\mathrm{C} 4$ dan $\mathrm{K} 2$, yang membahas mengenai persamaan yang terlihat dari hewan-hewan vertebrata yang disajikan dalam bentuk gambar. Kebanyakan peserta didik tidak menjawab dengan benar jenis pertanyaan tersebut, karena jenis soal tersebut termasuk dalam soal yang menganalisis jadi peserta didik harus berpikir secara detail dan memahami maksud dari soal yang ditanyakan. Sehingga jawaban yang dapat menjawab pertanyaan dengan jenis soal apapun dengan benar.

Berdasarkan hasil analisis tersebut, dapat disimpulkan bahwa beberapa materi yang dianggap mudah oleh peserta didik merupakan materi yang bersifat umum karena berkaitan dengan kehidupan sehari-hari. Sedangkan untuk beberapa materi yang dianggap sulit oleh peserta didik karena rata-rata dari mereka belum pernah melihat hewan tersebut sehingga hal tersebut membuat peserta didik harus mencari referensi lagi sebanyak mungkin mengenai sesuatu yang belum pernah mereka ketahui sebelumnya. Hal ini disebabkan karena pada indikator ciri-ciri vertebrata banyak terdapat istilah-istilah yang sulit dipahami. Jika peserta didik tidak memahami istilah tersebut maka peserta didik mengalami kesulitan dalam mengerjakan soal yang menyangkut istilah pada materi vertebrata ini. Hal yang sama diungkapkan dalam penelitian Machin (2012:163) bahwa salah satu kesulitan utama peserta didik disekolah menengah dalam mempelajari biologi adalah banyaknya istilah ilmiah. Kesulitan yang dialami peserta didik dalam memahami istilah ini sering disebabkan karena jarangnya peserta didik dalam membaca kamus biologi.

\section{d) Kesulitan Peserta didik Dalam Mempelajari Sub Materi Vertebrata}

Berdasarkan penelitian yang telah dilakukan, hasilnya menunjukan bahwa terlihat banyak peserta didik yang masih kurang dalam memahami sub materi vertebrata, hal tersebut terlihat dari perhitungan tes hasil belajar yang telah dilakukan. Terkait hal tersebut, peneliti melakukan tes wawancara bersama guru biologi MIPA SMAN di Tasikmalaya, yang bertujuan untuk mengetahui bagaimana kesulitan peserta didik dan kebiasaan didalam kelas saat belajar biologi dan saat mempelajari sub materi vertebrata, adapun kutipan wawancaranya dipaparkan sebagai berikut:

Peneliti : Model pembelajaran apa yang selalu bapa gunakan di dalam kelas?

Guru Bio : Discovery Learning untuk metode pembelajaran paling metode ceramah sama diskusi

Peneliti : Apakah bapa tau kebiasaan peserta didik saat mengikuti pelajaran biologi? Misalnya mereka cenderung bersemangat atau malah bermalas malasan begitu pak?

Guru Bio : : Kebiasaan mereka ya biasanya cenderung suka dengan pembelajaran yang bersifat nyata, seperti praktikum. Mereka biasanya bersemangat, karna kan bisa lihat secara langsung objek yang diamati. Tapi dikarenakan ada beberapa kendala seperti ada alat-alat praktikum yang kurang lengkap sehingga jarang diadakan praktikum. Sedangkan untuk pembelajaran biasa didalam kelas presentasi atau menjelaskan materi, mereka cenderung bosan, mungkin hanya beberapa peserta didik yang aktif pada saat pembelajaran, sehingga dibantu dengan metode diskusi untuk meningkatkan pola berpikir mereka.

Peneliti : Dan ternyata masih banyak peserta didik yang kurang paham mengenai persamaan dan perbedaan dari masing-masing hewan vertebrata. Apakah saat penjelasan didalam kelas semua hewan vertebrata sudah dijelaskan dengan rinci bagaimana 
karakteristik dan ciri khasnya masing-masing pak?

Guru Bio

: Untuk materi sebenarnya semua sudah dijelaskan, tetapi memang ada beberapa peserta didik yang masih belum mengetahui mengenai perbedaan ataupun persamaan dari hewan vertebrata, karena kan pembelajaran biologi itu bisa dikatakan banyak hafalan yang cenderung membuat mereka merasa kesulitan, selain itu juga untuk segi cara berpikir mereka kan berbeda-beda dan kebanyakan setahu saya untuk anak-anak masih kurang dalam memahami pembelajaran terutama biologi.

Peneliti : Begitu ya pak. Serta ternyata masih banyak peserta didik yang kesulitan dalam mengetahui macam-macam aves, serta tidak mengetahui hewan mana saja yang termasuk dalam hewan mamalia laut. Apakah bapa tau penyebab mengapa banyak peserta didik tidak mengerti soal tersebut?

Guru bio : Untuk kelompok aves itu kan jenisnya sangat banyak, jadi mereka masih keliru jika menciricirikan kelompok hewan aves. Dan mereka masih kurang mampu dalam menganalisis mengenai apa-apa saja hewan yang ada di biota laut. Karena tingkat berpikirnya mereka masih cenderung pada tingkat mengingat dan memahami saja.

Peneliti : Menurut bapa apa kesulitan peserta didik dalam mempelajari biologi? Khusunya pada materi vertebrata?

Guru bio $\quad$ : Kesulitan yang di alami peserta didik adalah dari segi mendalami materi, dan menganalisis berbagai macam hewan vertebrata hal tersebut yang membuat peserta didik merasa kesulitan..

Kutipan wawancara tersebut menunjukkan bahwa peserta didik mempunyai kebiasaan belajar disekolah dengan metode ceramah dan diskusi. Peserta didik cenderung lebih menyukai pembelajaran yang bersifat nyata dan berkaitan dengan praktek serta melaksanakan pembelajaran secara langsung menggunakan objek, karena hal tersebut membuat peserta didik bersemangat mengikuti pembelajaran biologi.

Sedangkan saat mendengarkan materi, kebanyakan dari peserta didik hanya fokus diawal pembelajaran saja dan mereka cenderung bosan jika terus-terusan mendengarkan ceramah, sehingga dibantu dengan metode diskusi yang selalu dilakukan didalam kelas agar kelas bersifat aktif. Hal tersebut sejalan dengan pendapat Rahim (2009:18) dalam penelitiannya mengatakan bahwa penggunaan metode pembelajaran yang kurang bervariasi dapat menyebabkan peserta didik kurang berminat untuk belajar. Akibatnya, prestasi belajar yang dicapai peserta didik kurang maksimal.

Temuan dalam penelitian ini adalah pengetahuan kognitif yang dimiliki oleh masingmasing peserta didik adalah berbeda-beda, tergantung dari bagaimana mereka dapat mengerti dan memahami pembahasan materi yang telah disampaikan oleh gurunya disekolah. Sudiarta (2013:4) mengatakan bahwa tingkat kecerdasan atau intelegensi peserta didik sangat menentukan tingkat keberhasilan belajar peserta didik. Selain itu, kemampuan peserta didik untuk dapat mengerti dan memahami suatu pembelajaran juga berbeda-beda tergantung pada cara gaya belajar dari masing-masing peserta didik dalam menyelesaikan suatu permasalahan. Berdasarkan hasil penelitian yang telah dilakukan, masih banyak peserta didik yang kurang baik bahkan gagal dalam memahami sub materi vertebrata.

Oleh karena itu, salah satu solusinya adalah dalam penelitian selanjutnya teknik pengumpulan data dalam penelitian ini ditambahkan dengan teknik pengumpulan data menggunakan angket, dan observasi, serta peneliti yang akan datang disarankan untuk ikut serta dalam pembelajaran berlangsung guna untuk mencari tau apa penyebab dari kenapa aspek kognitif peserta didik di kelas tersebut tidak maksimal, dan bagaimana proses pembelajarannya didalam kelas, apakah sudahberjalan dengan lancer atau justru sebaliknya, karena hal tersebut sesuai dengan pendapat dari Dimyati (2013:104) yang menjelaskan bahwa guru adalah pendidik dan sekaligus pembimbing dalam proses belajar yang harus memantau jalannya proses pembelajaran secara langsung. Sanjaya (2008:15) juga mengemukakan bahwa keberhasilan suatu system pembelajaran 
bergantung pada guru yang merupakan komponen penentu, hal ini disebabkan karena guru adalah orang yang langsung berhadapan dengan peserta didik sehingga guru dapat berperan sebagai perencana dan pelaksana pembelajaran.

Selain itu bisa ditambahkan juga dengan menghadirkan pembelajaran yang bermakna kepada peserta didik. Piaget dan David Ausubel dalam Trianto (2007:25) mengemukakan teori belajar bermakna, yang merupakan suatu proses mengkaitkan informasi baru pada konsepkonsep relevan yang terdapat pada struktur kognitif seseorang. Pada proses belajar peserta didik harus aktif melakukan kegiatan, aktif berpikir, menyusun konsep dan memberi makna tentang hal-hal yang sedang dipelajarinya. Sesuai dengan teori belajarnya yaitu yang menekankan agar guru mengetahui konsepkonsep yang telah dimiliki oleh peserta didik sehingga proses pembelajarannya dikatakan bermakna bagi peserta didik.

\section{SIMPULAN}

Berdasarkan hasil penelitian, pengumpulan data dan analisis data, maka dapat disimpulkan:

1) Dimensi pengetahuan kognitif peserta didik lebih baik pada pengetahuan faktual. Hal tersebut diakibatkan karena pada pengetahuan faktual jenis soalnya bersifat definisi dari suatu istilah tertentu yang mudah dimengerti oleh peserta didik. Sedangkan, pengetahuan konseptual merupakan pengetahuan yang lebih kompleks dan terorganisasi.

2) Dimensi proses kognitif yang dikuasai oleh peserta didik adalah pada $\mathrm{C} 1$, sedangkan yang kurang dikuasai oleh peserta didik adalah pada $\mathrm{C} 4$.

3) Penguasaan konsep peserta didik pada sub materi vertebrata memperoleh hasil bahwa ada beberapa materi yang dianggap mudah oleh peserta didik yang merupakan materi yang bersifat umum dan dapat diketahui oleh semua orang karena berkaitan dengan kehidupan sehari-hari, diantaranya yaitu mengenai pengertian vertebrata, pembahasan mengenai hewan pisces, dan materi mengenai seputar reptile.

4) Kesulitan peserta didik dalam mempelajari sub materi vertebrata dapat memperoleh hasil bahwa kesulitan yang dialami peserta didik dalam mempelajari vertebrata adalah dalam segi mendalami materi, karena banyaknya jenis hewan vertebrata yang harus dikuasai oleh peserta didik. Dan dalam segi menganalisis berbagai macam hewan vertebrata membuat peserta didik kesulitan untuk dapat memahami bentuk soal cerita mengenai hewan vertebrata yang ada dalam kehidupan sehari-hari.

\section{REFERENSI}

Anderson, L. W. and Krathwohl, David. R. (2001). Taxonomy for Learning, Teaching, and Assesing. A Revision of Bloom's Taxonomy of Educational Objectives. Abridged Edition. New York: Addison Wesley Longman, Inc.

Dimyati dan Mudjiono. (2009). Belajar dan Pembelajaran. Jakarta: Kerjasama Departemen Pendidikan dan Kebudayaan dengan Rineka Cipta.

Hidayati, Fajar. (2010). Kajian Kesulitan Belajar Siswa Kelas VII SMP Negeri 16 Yogyakarta Dalam Mempelajari Aljabar. Universitas Negeri Yogyakarta.

Machin, A. (2012). Pengaruh Permainan Call Cards terhadap Hasil Belajar dan Aktivitas Pembelajaran Biologi. Jurnal Pendidikan IPA Indonesia. 1(2): 163-167.

Rahim, U. (2009). Metode bervariasi dapat meningkatkan prestasi belajar matematika siswa Kelas V SD Negeri I Olo-Oloho Kecamatan Pakue Kabupaten Kolaka Utara. Majalah Ilmiah Pendidikan Matematika dan IPA, 8(1), 18-27.

Rifa'i, A dan Anni, C.T. (2016). Psikologi Pendidikan. Semarang: UPTUNNES Press.

Sanjaya, W. (2008). Perencanaan dan Desain Sistem Pembelajaran. Jakarta: Kencana Prenada Media Group.

Sudiarta, N., Marhaeni, A., \& Suhandana, A. (2013). Kontribusi Tingkat Intelegensi, Nilai Ujian Nasional Bahasa Inggris SMP, Minat Belajar Bahasa Inggris terhadap Prestasi Belajar Bahasa Inggris Siswa Kelas X SMA Negeri 2 Amlapura Tahun Pelajaran 2012/2013. Jurnal Program Pascasarjana Universitas Pendidikan Ganesha Program Studi Administrasi Pendidikan. Vol. 4.

Sudjana, Nana. (2006). Penilaian Hasil Proses Belajar Mengajar. Bandung: PT. Remaja 
Quagga: Jurnal Pendidikan dan Biologi

p-ISSN 1907-3089, e-ISSN2651-5869

Volume 13, Nomor 1, Januari 2021, pp.14-25

https://journal.uniku.ac.id/index.php/quagga

Rosdakarya.

Trianto. (2007). Model-model Pembelajaran Inovatif Berorientasi Konstruktivistik. Jakarta: Prestasi Pustaka.

Trianto. (2012). Mendesain Model Pembelajaran Inovatif-Progresif. Jakarta: Kencana Prenada Media Group.

Widodo. A. (2006). Profil Pertanyaan Guru dan Siswa dalam Pembelajaran Sains. Jurnal Pendidikan dan Pembelajaran. 4(2): 13914.

Yusriya, A., Santosa, K., \& Priyono, B. (2014). Pengembangan Video Pembelajaran Materi Klasifikasi Hewan Sebagai Suplemen Bahan Ajar Biologi SMP. Jurnal Pendidikan Biologi. 3(1): 26-34. 